\title{
Nonstructural Proteins of Herpes Simplex Virus
}

\section{Major Virus-Specific DNA-Binding Protein}

\author{
KENNETH L. POWELL, ${ }^{*}$ EDWARD LITTLER, AND DOROTHY J. M. PURIFOY \\ Department of Microbiology, University of Leeds, Leeds LS2 9JT, England
}

Received 10 February 1981/Accepted 20 May 1981

\begin{abstract}
The major herpes simplex virus type 2 DNA-binding infected cell-specific polypeptides 11 and 12 have been purified to homogeneity from extracts of virusinfected cells. Monospecific antiserum to the purified protein has been made and used to examine virus temperature-sensitive mutants for defects in the synthesis of the protein and to probe virus DNA synthesis in isolated chromatin. The purified protein acted directly on a polydeoxyadenylic acid-polydeoxythymidylic acid helix, reducing its melting temperature. The results indicated that the protein functions in virus DNA synthesis.
\end{abstract}

Herpes simplex virus type 1 (HSV-1) and type 2 (HSV-2) induce more than 50 proteins in infected cells as judged by one-dimensional polyacrylamide gel electrophoresis $(6,13)$. Many more proteins can be resolved by two-dimensional techniques (R. W. Honess, K. L. Powell, and $\mathrm{H}$. Marsden, personal communications). The function of all but a few of the proteins remains undefined.

We have previously associated a polypeptide of 150,000 molecular weight with the virus-specific DNA polymerase (15). A protein of about 44,000 molecular weight was associated with the virus-specific thymidine kinase (7), and a protein of 90,000 molecular weight was associated with the virus-induced alkaline exonuclease (21). The properties of the remaining polypeptides can only be discussed in vague terms, e.g., as structural and nonstructural proteins, etc.

As an attempt to begin an analysis of the virus-specific proteins involved in DNA synthesis, we and others $(2,18)$ have examined HSVinfected-cell DNA-binding proteins. These studies have identified a further group of virus proteins, those with an affinity for DNA, which may have a DNA-related function. The major HSVspecific DNA-binding protein (previously designated as infected cell-specific polypeptides 11 and 12 [ICSP 11,12] [18]), which corresponds to the HSV-1-infected-cell protein 8 (ICP 8) of Honess and Roizman (5), has the highest affinity of the virus proteins for DNA, binds more strongly to single-stranded than to doublestranded DNA, and binds more strongly to DNA cellulose when partially purified, properties which are reminiscent of the helix-destabilizing protein of bacteriophage $\mathrm{T} 4$ (8).

A quite separate reason for this study was to prepare reagents capable of sensitive detection of the ICSP 11,12 protein. Anzai et al. (1) detected antibody to ICSP 11,12 (designated VP134 in their study) in sera from cervical cancer patients, and the protein was also detected in HSV-transformed cells by Flannery et al. (4) (in their study, designated VP143). Therefore, a serum capable of sensitive detection of ICSP 11,12 was an important reagent to develop. Here, we report that we have purified the protein, prepared antisera to it, and examined some of its properties.

\section{MATERIALS AND METHODS}

Cells and viruses. The strains of virus used in this study were HSV-2 strain 186 and HSV-1 strain HFEM.

The HSV temperature-sensitive mutants used were $22 \mathrm{HSV}-1$ strain KOS mutants in complementation groups $\mathrm{A}$ to $\mathrm{O}$ and $9 \mathrm{HSV}-2$ strain 186 mutants in complementation groups A to $\mathrm{H}$ (19). The HSV-1 mutants belonged to complementation groups 1-1 to $1-14$, and the HSV-2 mutants belonged to complementation groups 2-2, 2-3, 2-5, 2-7, and 2-15 to 2-18. G. Aron, J. Esparza, and P. Schaffer kindly provided stocks of mutant virus. For all experiments, young confluent monolayers of HEp-2 cells were infected at an input multiplicity of 20 PFU per cell. The derivation of virus strains, methods for cell and virus propagation, and virus assay have been described previously $(14,17)$.

Production of radiolabeled virus proteins. Where labeled proteins were required, infected cells were incubated from 1 to $18 \mathrm{~h}$ postinfection in medium containing $2 \mu \mathrm{Ci}$ of ${ }^{14} \mathrm{C}$-labeled amino acid mixture (Radiochemical Centre, Amersham, England) per ml, the normal amounts of arginine, and reduced amounts of the other amino acids as described previously (13).

Protein extraction and purification. (i) Protein extraction. When maximum levels of the ICSP 11,12 protein were attained (about $18 \mathrm{~h}$ at $37^{\circ} \mathrm{C}$ postinfection 
[13]), HSV-2-infected HEp-2 cells were harvested by scraping. The infected cells were pooled in tubes on ice, and, after this stage, all procedures were undertaken at 0 to $4^{\circ} \mathrm{C}$. The cells were pelleted by low-speed centrifugation, washed in Tris buffer $(\mathrm{pH} 7.5)$, and suspended in extraction buffer $(20 \mathrm{mM}$ Tris-hydrochloride [ $\mathrm{pH} 7.5]$ and $0.5 \mathrm{mM}$ dithiothreitol) at a cell concentration of $1 \times 10^{7}$ to $3 \times 10^{7} / \mathrm{ml}$. The cells were then subjected to ultrasonic disruption and extracted with high salt as described previously (15). The extract was dialyzed overnight against several changes of $\mathrm{DE}$ buffer (50 mM Tris-hydrochloride [pH 7.5], $0.5 \mathrm{mM}$ dithiothreitol, $0.2 \%$ Nonidet P-40, and $20 \%$ glycerol). After dialysis, the extract was clarified by sedimentation at $15,000 \mathrm{rpm}$ for $20 \mathrm{~min}$; the supernatant fluid containing the ICSP 11,12 protein was used for purification.

(ii) DEAE-cellulose chromatography. The next step in ICSP 11,12 purification was accomplished by chromatography on a column $(2$ by $20 \mathrm{~cm})$ of DEAEcellulose (DE52, Whatman Ltd., Kent, England) equilibrated in DE buffer. The cell extract was applied to the column, the column was washed with 2 volumes of DE buffer, and ICSP 11,12 was eluted with a 150-ml gradient of 0 to $0.3 \mathrm{M} \mathrm{KCl}$ in DE buffer. Each fraction from the column was assayed for acid-precipitable radioactivity and was analyzed by polyacrylamide gel electrophoresis as described previously (13).

(iii) Phosphocellulose chromatography. The peak of ICSP 11,12 from the DEAE-cellulose column was dialyzed in DE buffer and was applied to a column ( 2 by $15 \mathrm{~cm}$ ) of phosphocellulose (P11 cellulose, Whatman). To prevent nonspecific adsorption, the column was washed with bovine serum albumin at $500 \mu \mathrm{g} / \mathrm{ml}$ in DE buffer and further washed with DE buffer before loading with ICSP 11,12. After loading, the column was washed with 2 volumes of DE buffer, and the ICSP 11,12 was eluted with a $100-\mathrm{ml}$ gradient of 0.1 to $0.4 \mathrm{M} \mathrm{KCl}$ in DE buffer. Assays on the column fractions were done exactly as described for DEAEcellulose column fractions.

(iv) DNA-cellulose chromatography. Denatured DNA-cellulose chromatography was as described previously (18). Fractions containing ICSP 11,12 from the phosphocellulose column were pooled, adjusted to a concentration of $500 \mu \mathrm{g} / \mathrm{ml}$ in bovine serum albumin, dialyzed against two changes of low-salt buffer $(50 \mathrm{mM}$ $\mathrm{KCl}$ ), and applied to the DNA-cellulose column. Elution was achieved by the stepwise addition of $0.05,0.1$, $0.2,0.4$, and $1.0 \mathrm{M} \mathrm{KCl}$ in buffer. The column fractions were assayed for ICSP 11,12 as described above for the DEAE-cellulose column fractions. The purified protein in concentrated form was obtained from the $1.0 \mathrm{M} \mathrm{KCl}$ eluate. About $200 \mu \mathrm{g}$ of pure ICSP 11,12 was obtained from $2 \times 10^{9}$ infected cells. The protein was pooled and dialyzed against suitable buffers for each experiment. The same procedure was used for purification of the HSV-1 major DNA-binding protein.

Serological tests. (i) Immunodiffusion. Immunodiffusion tests were done in 3-mm-thick layers of Ionagar no. 2 (Oxoid Ltd., London, England) in phosphate-buffered saline. The wells were arranged hexagonally, and each well was separated from its neighbor by $3 \mathrm{~mm}$ of gel.

(ii) Immunoprecipitation. Immunoprecipitation tests were done by the method of Honess and Watson (7) except that the immunoprecipitates were washed by six successive washes with phosphate-buffered saline followed by resuspension in saline. The precipitate was allowed to reform overnight and was finally collected by sedimentation.

(iii) Immunofluorescence. Immunofluorescence tests were done as described previously (16).

(iv) Complement fixation. Complement fixation tests were done as described by Sim and Watson (20).

Chromatin assays. Mock-infected-cell and infected-cell chromatins were prepared by the method of Yamada et al. (23). The assay mixture contained $100 \mathrm{mM}$ Tris-hydroxychloride ( $\mathrm{pH} \mathrm{7.5),} 5 \mathrm{mM}$ magnesium chloride, $250 \mu \mathrm{M}$ ATP, GTP, CTP, and UTP, and $250 \mu \mathrm{M}$ dATP, dGTP, and dCTP together with $2.5 \mu \mathrm{M}\left[{ }^{3} \mathrm{H}\right] \mathrm{TTP}$ (specific activity, $1.2 \mathrm{Ci} / \mathrm{mmol}$; Radiochemical Centre). To assess the effect of specific antisera on the chromatin preparations, antisera and chromatin were incubated together before their addition to reaction mixtures.

DNA polymerase assays. DNA polymerase assays and antiserum neutralization experiments were done as described previously (15).

Virus purification and DNA extraction. Enveloped HSV-1 (strain HFEM) particles were purified by the method of Powell and Watson (16). Virus DNA was extracted with phenol followed by chloroform and butanol and then precipitated with ethanol before use. Control DNA was prepared from HEp-2 cells by a similar method.

Antiserum preparation. The pure protein (ICSP 11,12 ) was homogenized in an equal volume of incomplete Freund adjuvant, and $10 \mu \mathrm{g}$ of protein was injected into the front footpads of New Zealand white rabbits. After 2 weeks, the rabbits received a second injection via the rear footpads. The rabbits were bled after a further 10 days.

Spectrophotometric assays of DNA denaturation. Denaturation of a polydeoxyadenylic acid-polydeoxythymidylic acid helix was measured in a Cecil spectrophotometer fitted with a thermostatted microcell (Hellma Ltd.; total volume, $225 \mu \mathrm{l}$ ). Mixtures of DNA helix (polydeoxyadenylic acid-polydeoxythymidylic acid; Sigma) and proteins were made, the temperature was then raised to $40^{\circ} \mathrm{C}$, and the reaction was monitored at $260 \mathrm{nM}$. In some experiments, HSV major DNA-binding protein was preincubated with anti-ICSP 11,12 gamma globulin (prepared by ammonium sulfate precipitation of anti-ICSP 11,12 serum) for $5 \mathrm{~min}$ at $37^{\circ} \mathrm{C}$. The final ratio of DNA-binding protein to DNA was the same as in all other experiments.

\section{RESULTS}

Purification of ICSP 11,12. Previous experiments had shown that the synthesis of ICSP 11,12 began soon after the initiation of infection, peaked at 4 to $8 \mathrm{~h}$ postinfection, and declined slowly thereafter (13).

Therefore, to maximize the yield of the protein, cells infected for 16 to $18 \mathrm{~h}$ were used as a source of the protein. We had previously shown 
that ICSP 11,12 was efficiently extracted with high salt from infected cells (18). Therefore, a high-salt extract of infected cells was used as starting material for purification, and the following purification scheme was evolved.

ICSP 11,12 constitutes a major proportion of infected-cell protein synthesis (see Fig. 2), and on DEAE-cellulose chromatography, the protein behaves like many other virus proteins binding to the column and eluting with 0.1 to $0.2 \mathrm{M} \mathrm{KCl}$ (Fig. 1). Thus, as can be seen in Fig. 2, the peak fractions of the column were enriched for ICSP 11,12 but still contained other virus proteins; even so, a considerable purification from host cell proteins was obtained. The fractions containing ICSP 11,12 (dotted line, Fig. 1) were pooled and applied to a column of phosphocellulose (Whatman P11). ICSP 11,12 exhibited an unusual property on this column, binding weakly to phosphocellulose in the absence of salt and eluting with less than $0.1 \mathrm{M} \mathrm{KCl}$ (Fig. 1B). Thus, from this column, the ICSP 11,12 eluted as a

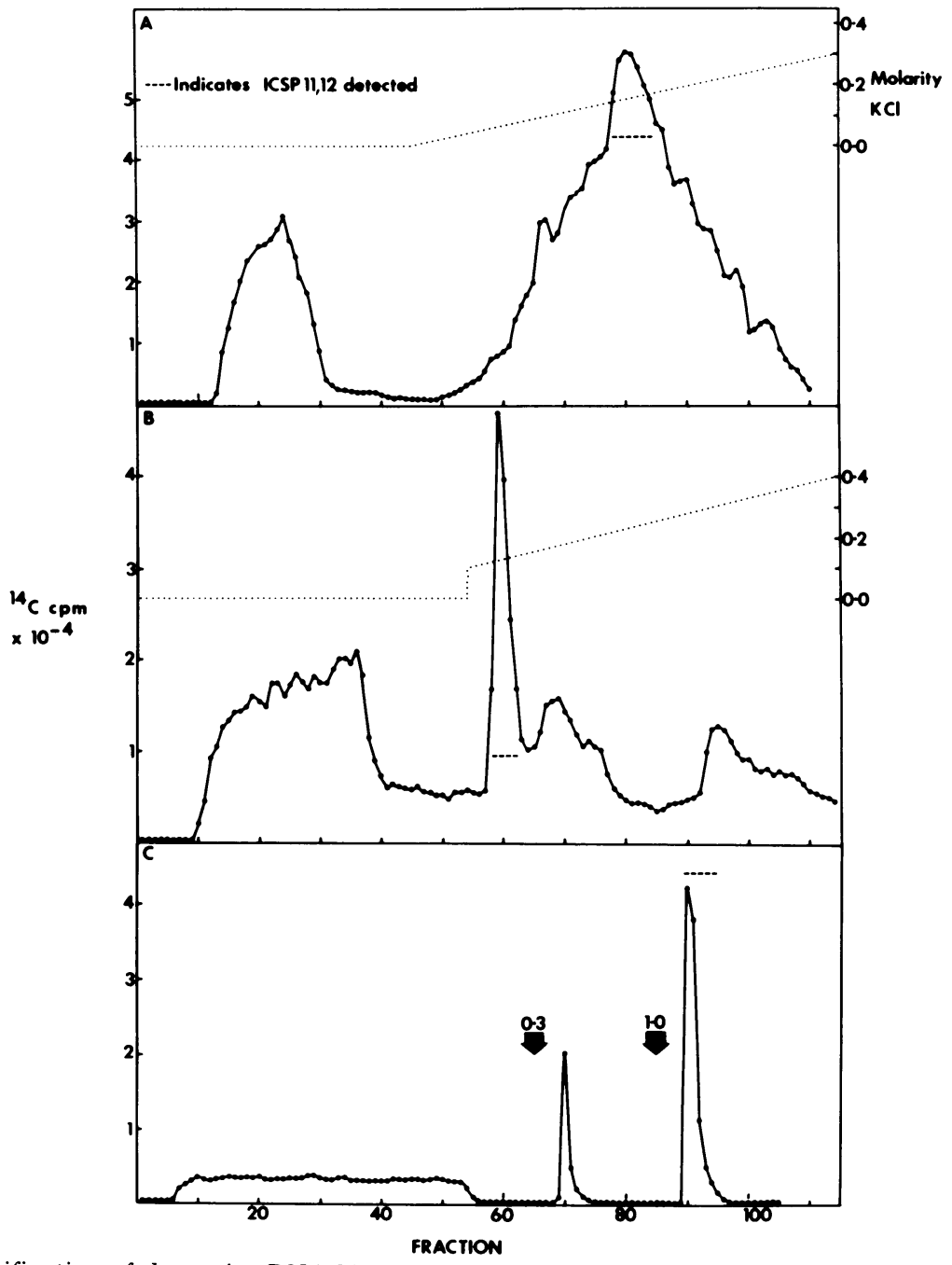

FIG. 1. Purification of the major DNA-binding protein ICSP 11,12 from HSV-2-infected cells. Cells were disrupted by sonication and extracted under high-salt conditions, and the extracts were dialyzed against DE buffer. Subsequent purification was by chromatography on DEAE-cellulose (A) followed by phosphocellulose (B) and finally by DNA-cellulose (C). Total acid-precipitable radioactivity (O) is shown for each column. Each column fraction was analyzed by polyacrylamide gel electrophoresis, and fractions containing ICSP 11,12 are indicated by the dashed lines. The molarity of $\mathrm{KCl}$ of fractions is shown in $A$ and $B$, wherein a continuous-gradient elution was used. The DNA-cellulose column (C) was eluted in stepwise fashion, and the position where 0.3 and $1.0 \mathrm{M} \mathrm{KCl}$ was applied is indicated by arrows. 


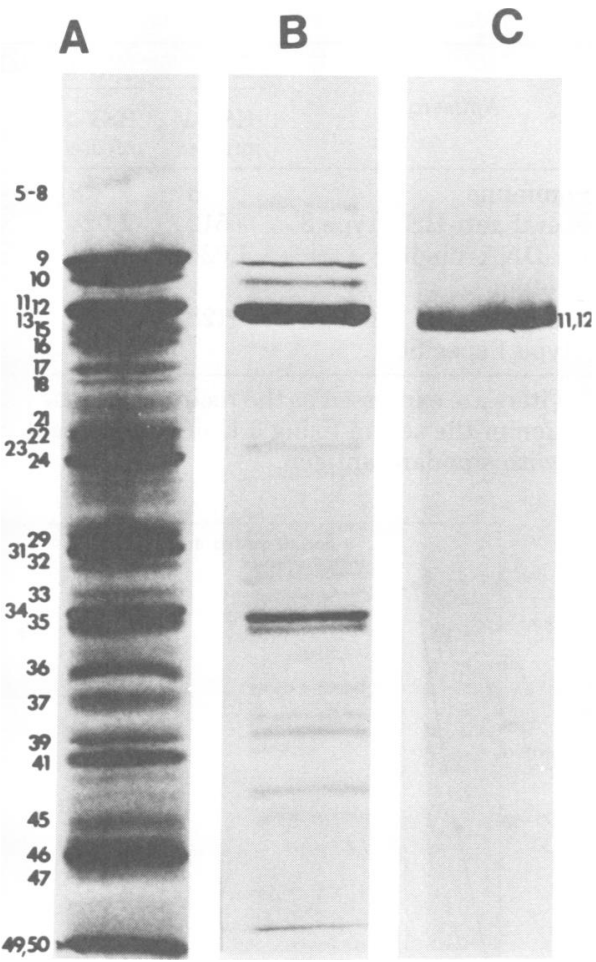

FIG. 2. Sodium dodecyl sulfate-polyacrylamide gel electrophoresis of samples from various stages of purification of HSV-2 ICSP 11,12. Samples of the pool of fractions indicated by dashed lines in Fig. $1 A$ for $D E A E$-cellulose (B) and Fig. $1 C$ for DNA-cellulose $(C)$ are shown. The whole-cell extract $(A)$ and $D E A E$. cellulose samples were analyzed by autoradiography of the stained gel; the DNA-cellulose sample analysis shown is a stained gel.

single peak of radioactivity contaminated with minor amounts of cell and virus proteins.

We were already aware that ICSP 11,12 could be separated from other virus proteins by DNAcellulose chromatography (18). It was not surprising, therefore, that the peak fractions from phosphocellulose columns could be rendered pure in ICSP 11,12 by using this method. The peak fractions from the phosphocellulose column were pooled, dialyzed, and applied to a column of denatured DNA-cellulose. As expected, ICSP 11,12 bound strongly to the column and was eluted with $1 \mathrm{M} \mathrm{KCl}$. The ICSP 11,12 in the peak fractions from this column was found to be homogeneous, forming a single stained band on polyacrylamide gels (Fig. 2).

Virus specificity of ICSP 11,12. The purity and serological character of the purified ICSP 11,12 protein was tested by immunodiffusion with two general antisera to either HSV-1- or HSV-2-infected RK13 cells grown in rabbit se- rum. Such sera have been shown previously to be specific for virus antigens $(5,22)$. Although the sera gave multiple lines with an extract of HSV-2-infected cells (Fig. 3), they gave a single line with the purified protein. The line obtained with the purified protein was one of the lines obtained with both the general antisera and HSV-2-infected cells. This result indicated that the HSV-2 protein shared considerable crossreactivity with its HSV-1 homolog and was additional evidence for the virus specificity and purity of the product.

Preparation of antiserum to ICSP 11,12. ICSP 11,12 serum was prepared by injection of the purified protein into the rabbit footpad as described above. The antiserum produced was initially tested by using immunodiffusion and complement fixation tests. Immunodiffusion revealed that the antiserum gave a single line with the purified ICSP 11,12 (Fig. 3A) and with either HSV-1- or HSV-2-infected cells and that there was complete identity between the two lines (Fig. 3B). Thus, by this method, at least there appears to be almost complete identity between the ICSP 11,12 proteins of HSV-1 and HSV-2. These results were confirmed by complement fixation tests (Table 1). The antiserum gave identical and very high titers with both HSV-1and HSV-2-infected cells, although an HSV-1specific antiserum prepared as described previously (12) clearly differentiated the two antigen preparations. ICSP 11,12 antiserum did not react in this test with uninfected cells.

The specificity of the antiserum was then tested by immunoprecipitation tests. The serum precipitated only ICSP 11,12 from an extract of virus-infected cells (Fig. 4). This test was a direct immunoprecipitation test at a ratio of antiserum to antigen of $1 / 20$ by volume. This represented an excess of antiserum in the test (Fig. 4), and no further proteins could be precipitated by using more serum.

DNA-binding capacity of purified ICSP 11,12. ICSP 11,12 binds strongly to DNA-cellulose but not to cellulose alone (18). To test its capacity to bind DNA more directly, a filter binding assay was used (9). In this assay, labeled host cell or viral DNA was mixed with the purified ICSP 11,12, and its retention to filters $(0.45-\mu \mathrm{m}$ pore size; Millipore Corp., Bedford, Mass.) was measured. Under these conditions, essentially no DNA was bound to the filter in the absence of the DNA-binding protein or in the presence of a control protein (bovine serum albumin); when increasing amounts of the protein were added, the DNA was retained on the filter. The protein showed no apparent preference for whole virus or cellular DNA (Fig. 5).

Effect of antiserum to ICSP 11,12 on in 

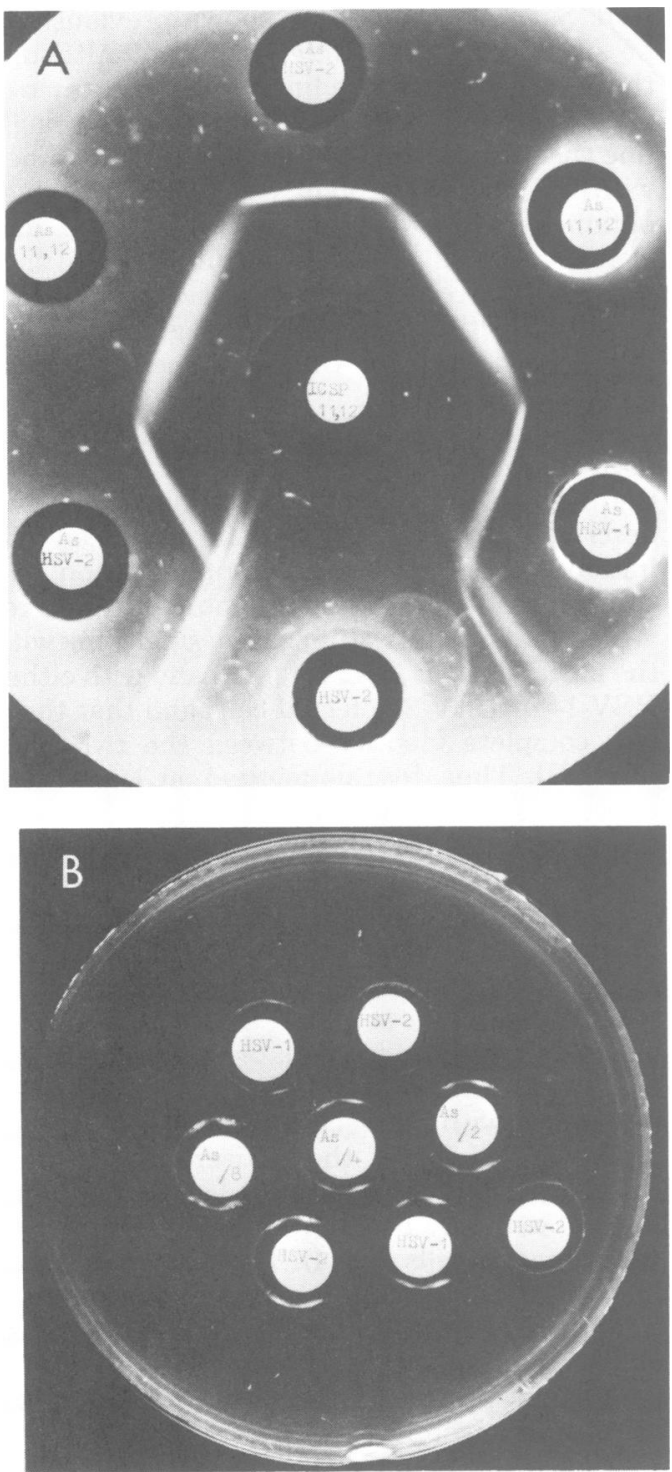

Fig. 3. Immunodiffusion tests of purified ICSP 11,12 and infected-cell extracts with antiserum to the purified ICSP 11,12 and antiserum to HSV-1- or HSV-2-infected-cell extracts. A. Purified ICSP 11,12 from the $1 M$ peak fractions from DNA-cellulose occupied the central well with an HSV-2-infected-cell extract in the bottom well. General antiserum to HSV. 1 or HSV-2 or antiserum to ICSP 11,12 were as indicated and were not diluted. B. Antiserum to ICSP 11,12 was in the central row of wells at dilutions from 1:2 to 1:8 as indicated. HSV-1- and HSV-2-infectedcell extracts were at a cell concentration of $5 \times 10^{8} /$ $m l$.

vitro virus DNA synthesis. Virus DNA synthesis in isolated chromatin was studied by the method of Yamada et al. (23). In the absence of
TABLE 1. Complement fixation test data

\begin{tabular}{lrcc}
\hline & \multicolumn{3}{c}{ Titer $^{a}$ for following cells: } \\
\cline { 2 - 4 } \multicolumn{1}{c}{ Antiserum } & $\begin{array}{c}\text { HSV-1 } \\
\text { infected }\end{array}$ & $\begin{array}{c}\text { HSV-2 } \\
\text { infected }\end{array}$ & HEp-2 \\
\hline Preimmune & $<8$ & $<8$ & $<8$ \\
General anti-HSV type 2 & 512 & 1,024 & $<8$ \\
$\begin{array}{c}\text { Anti-DNA-binding } \\
\text { protein }\end{array}$ & 1,024 & 1,024 & $<8$ \\
$\begin{array}{c}\text { Anti-HSV-1 Vp 2/3 } \\
\text { (type 1 specific) }\end{array}$ & 128 & $<8$ & $<8$ \\
\hline
\end{tabular}

${ }^{a}$ Titers are expressed as the reciprocal of the highest dilution of the serum fixing $3 \mathrm{U}$ of complement in the test with standard antigen.

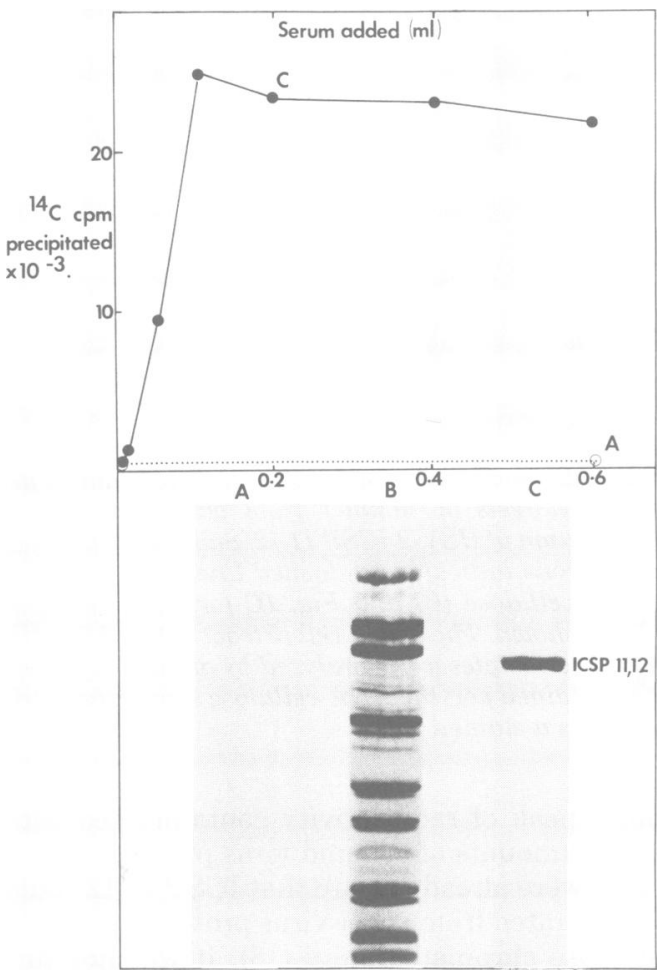

Fig. 4. Immunoprecipitation of ${ }^{14} \mathrm{C}$-amino acidlabeled protein from $H S V$-2-infected-cell extracts with antisera to purified ICSP 11,12 (O) compared with control preimmune rabbit serum (O). Autoradiographs of polyacrylamide gel electrophoresis of samples are shown beneath the diagram; A, Proteins precipitated by preimmune rabbit serum; $B$, infectedcell extracts; $C$, Proteins precipitated by anti-ICSP 11,12 serum.

any additional protein, virus DNA synthesis was linear for about 10 min when the rate of DNA synthesis began to decline (Fig. 6A). DNA synthesis in this system could be inhibited by antiserum to the HSV DNA polymerase, but not by an antiserum reactive with a virus-specific pro- 


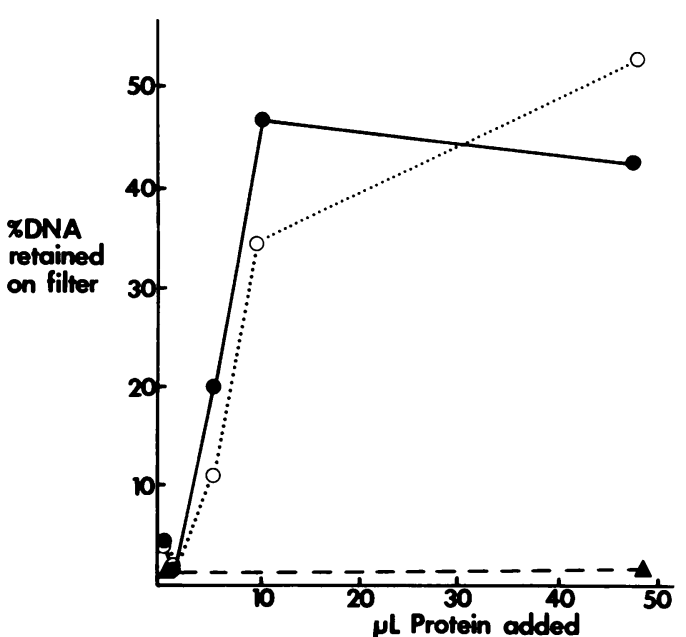

FIG. 5. Filter binding assay to determine binding of ICSP 11,12 to native HSV DNA (O) or HEp-2 cellular DNA (O). Cell DNA or virus DNA labeled with $\left[{ }^{3} \mathrm{H}\right]$ thymidine (specific activity, $1.7 \times 10^{5} \mathrm{cpm}$ ) $\mu g)$ was mixed with ICSP 11,12 at $200 \mu \mathrm{g} / \mathrm{ml}$ as indicated and tested for filter binding compared with viral DNA with bovine serum albumin $(\Delta) ; 100 \%$ $D N A$ represents $30,000 \mathrm{cpm}$.

tein, ICSP 32. Antiserum to the DNA-binding protein strongly inhibited DNA synthesis under the same conditions. The trivial explanation of this result, that antiserum to the DNA-binding protein was contaminated with antibody to the DNA polymerase, was ruled out by testing the antiserum against the polymerase enzyme (Fig. $6 \mathrm{~B})$. The antiserum had little effect on the polymerase, whereas under the same conditions, antiserum to the DNA polymerase abolished the enzyme activity. These results suggested that ICSP 11,12 was involved in DNA replication; similar observations previously indicated that the HSV DNA polymerase was essential for the DNA replication observed in isolated chromatin from infected cells (23).

Use of antiserum to the major DNA-binding protein to study cells infected with wild-type virus or temperature-sensitive mutants of HSV. The antiserum to ICSP 11,12 was next used in immunofluorescence tests to examine the site of accumulation of the protein in infected cells. As can be seen from Fig. 7A, HSV-2-infected cells gave bright nuclear fluorescence with the serum, whereas the same cells gave a generalized fluorescence with general antiserum to HSV-2-infected cells (Fig. 7B). No reaction was obtained between the serum and uninfected cells (data not shown). Immunofluorescence tests were next used with the monospecific anti-ICSP 11,12 serum to examine cells infected with temperature-sensitive mutants of
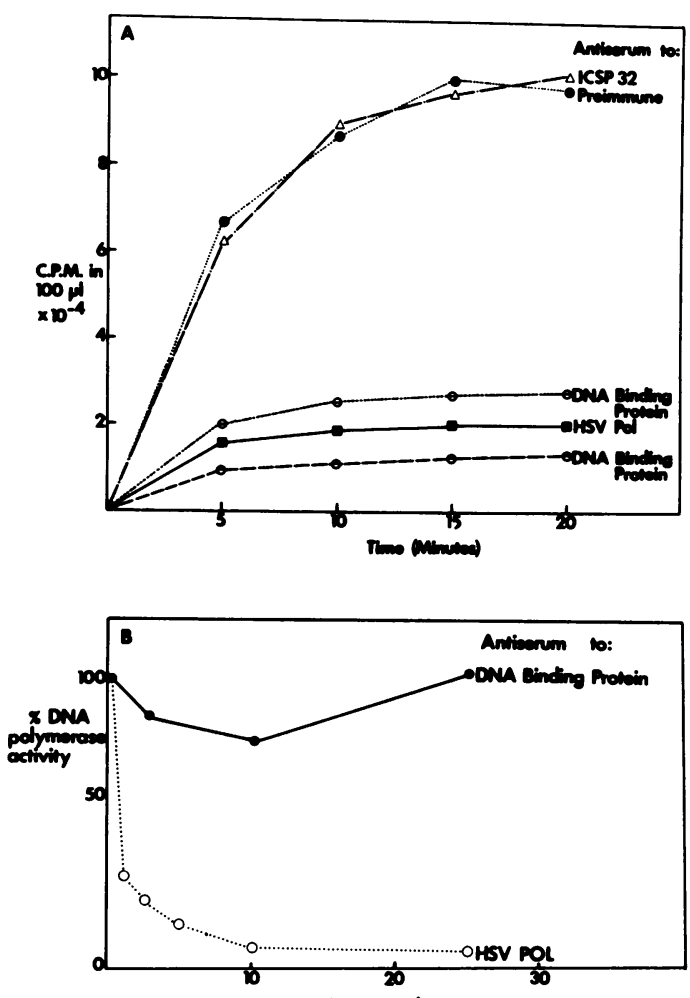

pl serum in aseoy

Fig. 6. Neutralization of in vitro DNA synthesis in isolated chromatin from $\mathrm{HSV}$-2-infected cells $(A)$ and of HSV DNA polymerase activity (B). (A) Neutralization tests were done by preincubation of iso. lated chromatin preparations with serum for $1 \mathrm{~h}$ at $0^{\circ} \mathrm{C}$, followed by standard assay at $37^{\circ} \mathrm{C}$. Symbols: (ด) preimmune serum; $(\triangle)$ anti-ICSP 32 serum; (घ) anti-HSV-2 DNA polymerase (purified) serum; $(\theta)$ and $(\Theta)$, two preparations of anti-ICSP 11,12 serum. (B) Neutralization tests of HSV.2 DNA polymerase were done by preincubation of enzyme and serum at room temperature for $1 \mathrm{~h}$ before a standard assay at $37^{\circ}$ C. Symbols: (O) anti-ICSP 11,12 serum; $(O)$ antiHSV.2 DNA polymerase (purified) serum.

HSV-1 and HSV-2. The temperature-sensitive mutants used included $22 \mathrm{HSV}-1$ mutants belonging to 15 complementation groups and 9 HSV-2 mutants belonging to 8 complementation groups (19). The only mutant which was abnormal by this test was tsH9 of HSV-2 (complementation group 2-2), wherein an accumulation of ICSP 11,12 occurred in the cytoplasm of infected cells at the nonpermissive temperature (Fig. 7C). The cells infected by the mutant gave the normal pattern of fluorescence at the permissive temperature. It might be argued that the mutant was deficient in the transport of ICSP 11,12 rather than in the synthesis of the protein per se, but general antisera stained the 

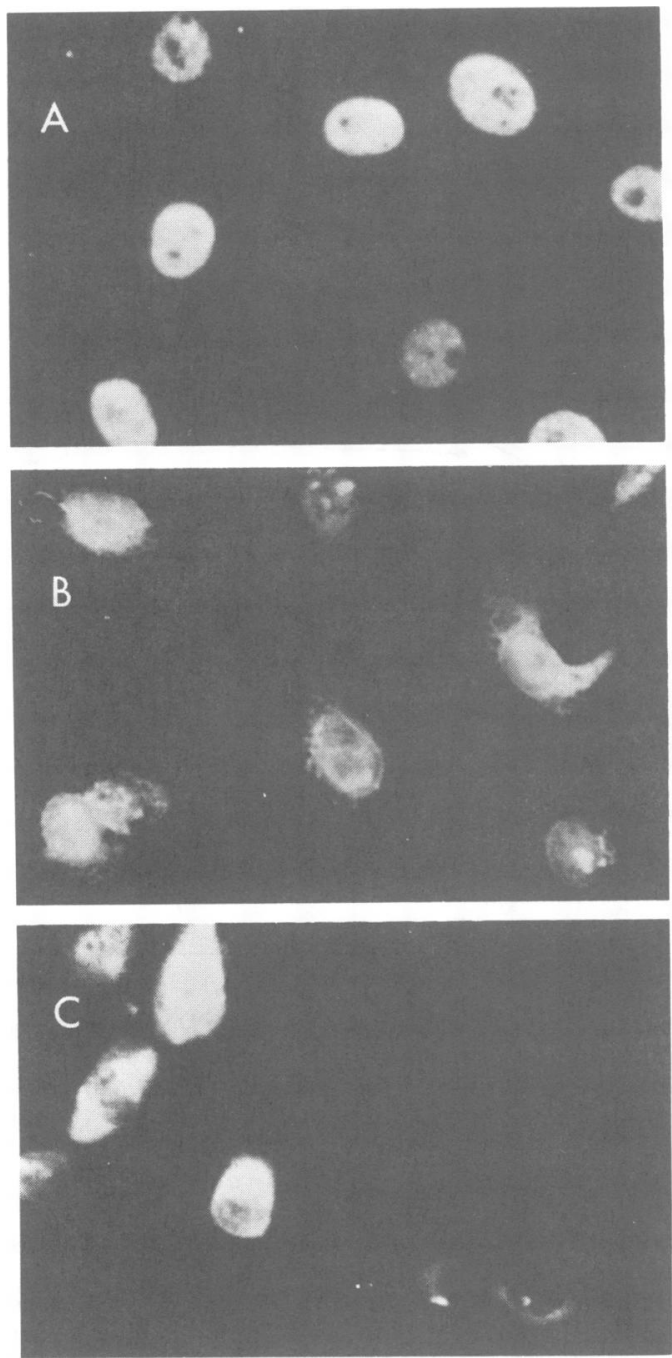

Fig. 7. Indirect immunofluorescent antibody tests of (A) HSV-2-infected cells treated with anti-ICSP 11,12 serum; (B) HSV-2-infected cells with general antiserum to HSV-2-infected cells; and (C) cells infected with HSV-2 temperature-sensitive mutant $\mathrm{H} 9$ and stained with anti-ICSP 11,12 serum.

nucleus of tsH9-infected cells even at the nonpermissive temperature.

Effect of purified ICSP 11,12 on a polydeoxyadenylic acid-polydeoxythymidylic acid helix. Many DNA-binding proteins have the effect of melting suitable DNA helixes (8). ICSP 11,12 has this property. ICSP 11,12 alone caused the denaturation of polydeoxyadenylic acid-polydeoxythymidylic acid at $40^{\circ} \mathrm{C}$, whereas no effect was observed in the presence of control proteins (Fig. 8) or in the presence of ICSP 11,12 purified from temperature-sensitive $\mathrm{H} 9$-infected

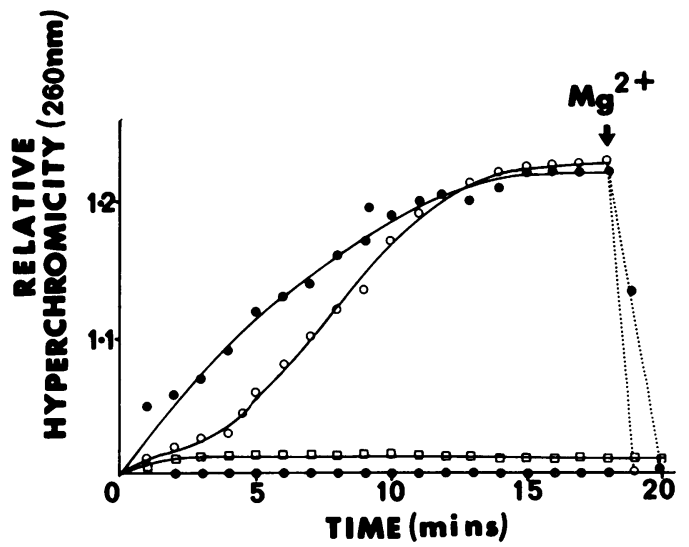

FIG. 8. Denaturation of polydeoxyadenylic acidpolydeoxythymidylic acid by HSV major DNA-binding protein. HSV-1 (O) or HSV-2 (O) major DNA. binding proteins were mixed with polydeoxyadenylic acid-polydeoxythymidylic acid at a ratio of $10 \mu \mathrm{g}$ of protein per $1 \mu \mathrm{g}$ of DNA. Controls without protein $(\square)$ or with bovine serum albumin $(\theta)$ are also shown. The mixture was incubated at $40^{\circ} \mathrm{C}$, and the reaction was monitored at $260 \mathrm{~nm}$. When absorbance had stopped increasing, magnesium chloride was added to give a final concentration of $0.04 \mathrm{mM} \mathrm{Mg}^{2+}$, and the effect on absorbance was recorded. The result of preincubation of HSV-1 major DNA-binding protein with anti-ICSP 11,12 gamma globulin is also shown (D).

cells. This activity of ICSP 11,12 could be entirely prevented by antiserum to ICSP 11,12 but not by preimmune serum. Similar results were obtained with the analogous DNA-binding protein from HSV-1-infected cells.

\section{DISCUSSION}

The purification of the major virus-specific DNA-binding protein represents the first purification of a nonstructural herpes simplex virus protein without an enzyme activity marker. Although the first purifications of the protein were achieved with polyacrylamide gels to locate the polypeptide, we are now able to do this by using antiserum to the purified protein in immunodiffusion tests. Thus, we are able to purify the protein simply and rapidly. Until an activity of the protein which can be assayed is available, we are not able to comment on the state of the purified product.

One of the aims of this work was to obtain antiserum to the major DNA-binding protein. We have achieved this with sera of high titers and extreme specificities. The production of such a serum has enabled us to screen temperature-sensitive mutant-infected cells and identify mutants deficient in the synthesis of ICSP 11,12 . The serum has also been used in studies 
of other herpesviruses. We have found that the protein is apparently identical with HSV-1 and HSV-2 (24), and, in addition, have shown that five different herpesviruses induce proteins showing antigenic determinants in common with those of HSV-2 ICSP 11,12 (24). This result would imply a need to conserve this protein for survival of the virus. The properties of the protein, i.e., DNA affinity, effect of antiserum to ICSP 11,12 on in vitro DNA synthesis, its conservation among the members of group, and the isolation of DNA-negative mutants defective in the protein, all suggest that ICSP 11,12 has a central role in virus DNA synthesis. It is difficult for us to imagine why its structure would be so tightly conserved among group members when few other features are, unless there are several constraints on changes in the structure of the protein. If the polypeptide also functions in virus assembly, for example, such conservation might be explained.

A further use of antiserum to ICSP 11,12 has been to study the expression of this HSV-2 antigen in human cervical cancer tissue and in cancer of the vulva $(3,10$; Kaufman et al., submitted for publication). In each of these studies, expression of the antigen has been observed in tumor tissue. Obviously, since our results have suggested that other herpesviruses induce a similar protein, it has become important to discover which virus is involved. This also applies to other work implicating the same protein in cervical cancer $(1,11)$, using antiserum to infectedcell fractions containing this protein.

The purification of HSV-2 ICSP 11,12 reported in this communication has enabled both the study of the purified protein for function and the preparation of antiserum to study the expression of the antigen. We are currently extending this approach by making monoclonal antisera to ICSP 11,12. Such antisera will enable us to examine some of the questions posed above.

\section{ACKNOWLEDGMENTS}

This work was initiated in the Department of Virology, Baylor College of Medicine, Houston, Tex.

We thank J. L. Melnick and D. H. Watson for their encouragement.

In Leeds, this work was supported by Public Health Service grant AI 15034 from the National Institute of Allergy and Infectious Diseases and by a grant from the Medical Research Council (United Kingdom).

\section{ADDENDUM}

Since submission of this report, an HSV-1 mutant with a probable temperature-sensitive lesion in ICP 8 , the analog of HSV-2 ICSP 11,12, has been isolated by in vitro mutagenesis (A. J. Conley, D. M. Knipe, P. C. Jones, and B. Roizman, J. Virol. 37:191-206, 1981).

\section{LTERATURE CITED}

1. Anzai, T., G. R. Dreesman, R. J. Courtney, E. Adam, W. E. Rawls, and M. Benyesh-Melnick. 1975. Antibody to herpes simplex virus type 2 -induced non-structural proteins in women with cervical cancer and control groups. J. Natl. Cancer Inst. 54:1051-1059.

2. Bayliss, G. J., H. S. Marsden, and J. Hay. 1975. Herpes simplex virus proteins: DNA binding proteins in infected cells and in the virus structure. Virology 68:124134.

3. Dreesman, G. R., J. Burek, E. Adam, R. H. Kaufman, J. L. Melnick, K. L. Powell, and D. J. Purifoy. 1980. Expression of herpesvirus induced antigens in human cervical cancer. Nature (London) 285:591-593.

4. Flannery, V. L., R. J. Courtney, and P. A. Schaffer. 1977. Expression of an early, nonstructural antigen of herpes simplex virus in cells transformed by herpes simplex virus. J. Virol. 21:284-291.

5. Honess, R. W., K. L. Powell, D. J. Robinson, C. Sim, and D. H. Watson. 1974. Type specific and type common antigens in cells infected with herpes simplex virus type 1 and on the surfaces of naked and enveloped particles of the virus. J. Gen. Virol. 22:159-169.

6. Honess, R. W., and B. Roizman. 1973. Proteins specified by herpes simplex virus. XI. Identification and relative molar rates of synthesis of structural and nonstructural herpes virus polypeptides in the infected cell. J. Virol. 12:1347-1365.

7. Honess, R. W., and D. H. Watson. 1974. Herpes virusspecific polypeptides studied by polyacrylamide gel electrophoresis of immunoprecipitates. J. Gen. Virol. 22:171-175.

8. Kornberg, A. 1980. DNA replication, p. 277-291. W. H. Freeman \& Co., San Francisco, Calif.

9. Lin, S-Y., and A. Riggs. 1972. Lac repressor binding to non-operator DNA: detailed studies and a comparison of equilibrium and rate competition methods. J. Mol. Biol. 72:671-690.

10. McDougall, J. K., D. A. Galloway, D. J. Purifoy, K. L. Powell, R. M. Richart, and C. M. Fenoglio. 1980. Herpes simplex virus expression in latently infected ganglion cells and in cervical neoplasia. Cold Spring Harbor Conf. Cell. Proliferation 7:101-116.

11. Melnick, J. L., R. J. Courtney, K. L. Powell, P. A. Schaffer, M. Benyesh-Melnick, G. R. Dreesman, T. Anzai, and E. Adam. 1976. Studies on herpes simplex virus and cancer. Cancer Res. 36:845-846.

12. Powell, K. L., A. Buchan, C. Sim, and D. H. Watson. 1974. Type specific protein in herpes simplex virus envelope reacts with neutralising antibody. Nature (London) 249:360-361.

13. Powell, K. L., and R. J. Courtney. 1975. Polypeptides synthesized in herpes simplex virus type 2-infected HEp-2 cells. Virology 66:217-228.

14. Powell, K. L., R. Mirkovic, and R. J. Courtney. 1977. Comparative analysis of polypeptides induced by type 1 and type 2 strains of herpes simplex virus. Intervirology 8:18-29.

15. Powell, K. L., and D. J. M. Purifoy. 1977. Nonstructural proteins of herpes simplex virus. I. Purification of the induced DNA polymerase. J. Virol. 24:618-626.

16. Powell, K. L., and D. H. Watson. 1975. Some structural antigens of herpes simplex virus type 1. J. Gen. Virol. 29:167-178.

17. Purifoy, D. J. M., and M. Benyesh-Melnick. 1975. DNA synthesis and DNA polymerase activity of herpes simplex virus type 2 temperature-sensitive mutants. Virology 68:374-386.

18. Purifoy, D. J. M., and K. L. Powell. 1976. DNA binding proteins induced by herpes simplex virus type 2 in HEp2 cells. J. Virol. 19:717-731.

19. Schaffer, P. A., V. C. Carter, and M. C. Timbury. 1978. Collaborative complementation study of temperature- 
sensitive mutants of herpes simplex virus types 1 and 2 . J. Virol. 27:490-504

20. Sim, C., and D. H. Watson. 1973. The role of type specific and cross reacting structural antigens in the neutralisation of herpes simplex virus types 1 and 2 . J. Gen. Virol. 19:217-233.

21. Strobel-Fidler, M., and B. Francke. 1980. Alkaline deoxyribonuclease induced by herpes simplex virus type 1: composition and properties of the purified enzyme. Virology 103:493-501.

22. Watson, D. H., W. I. H. Shedden, A. Elliot, T. Tetsuka,
P. Wildy, D. Bourgaux-Ramoisy, and E. Gold. 1966. Virus specific antigens in mammalian cells infected with herpes simplex virus. Immunology 11:399-408.

23. Yamada, M., G. Brun, and A. Weissbach. 1978. Synthesis of viral and host DNA in isolated chromatin from herpes simplex virus-infected HeLa cells. J. Virol. 26: 281-290.

24. Yeo, J., R. A. Killington, D. H. Watson, and K. L. Powell. 1981. Studies on cross-reactive antigens in the herpesviruses. Virology 108:256-266. 